DOI 10.36622/VSTU.2021.51.3.008

UDC $625.7 / .8$

N. V. Shchegoleva ${ }^{1}$, V. V. Stolyarov ${ }^{2}$, A. V. Kochetkov ${ }^{3}$

\title{
THE PROCEDURE OF ANALYSIS, ASSESSMENT AND RISK REDUCTION OF VEHICLE COLLISIONS ON A MULTI-LANE ROAD
}

\author{
Saratov State Technical University Named after Y. A. Gagarin ${ }^{1,2}$ \\ Russia, Saratov \\ Perm National Research Polytechnic University ${ }^{3}$ \\ Russia, Perm
}

\author{
${ }^{1}$ PhD in Engineering, Assoc. Prof., Dept. of Transport Construction, tel.: 8-937-256-86-30, \\ e-mail: Shegoleva123@mail.ru \\ ${ }^{2}$ D. Sc. in Engineering, Prof., Dept. of Transport Construction, tel.: 8-917-217-75-10, \\ e-mail: stolyarov_v_v@mail.ru \\ ${ }^{3}$ D. Sc. in Engineering, Prof., Dept. of Cars and Technological Machines, tel.: 8-906-306-95-53, \\ e-mail: soni.81@mail.ru
}

\begin{abstract}
Statement of the problem. The problem of ensuring the safety of vehicles on a multi-lane roadway of the required width of coverage is considered based on the risk-oriented approach, in accordance with the Federal law of the Russian Federation No. 184 - FZ "on technical regulation". Results. The authors presented the applicability of the algorithm to assess the risk of interaction of vehicles on six-lane highways for determining regulatory performance; identify the required values of coating thickness for the design; decision-making on the improvement of the transverse profile when major repairs and reconstruction, as well as to develop recommendations for ODD.

Conclusions. It was found that in normative documents for design of six-lane roads, the design vehicle should provide the change of normalized coating thickness, increasing it to values at which the risk of collision of vehicles does not exceed the permissible value.
\end{abstract}

Keywords: risk theory, technical regulation, six-lane highway, roadway width, permissible risk, provided speed, traffic safety.

Introduction. What makes the study at hand particularly relevant is the compulsory application of a risk-oriented approach for all areas of road management, including recommendations for development, design, construction and operation (maintenance, repair and reconstruction) of roads. In an earlier published [9], the influence of the parameters of the width of the surfacing on the safety of vehicles was shown and a method for identifying the permissible speed on narrow sections of the highway based on the amount of allowable risk was developed. 
On top of the issues discussed in this article, it is necessary to establish the required and acceptable parameters of the width of the surfacing of multi-lane roads on the basis of risk assessments. Previously, in view of the risk analysis, the joint solution of a number of problems was not considered, including: normalization of the width of lanes and edge lanes; design of a cross section of a multilane road and quality of construction of road elements. The aim of the study is to assign the width of the surfacing of multi-lane roads in compliance with the riskoriented approach, in accordance with the Federal Law of the Russian Federation № 184 Federal Law "On Technical Regulation".

\section{Algorithm for calculating the risk of overtaking lane changes on a six-lane highway.}

From the viewpoint of traffic safety, the major element of the cross profile of the road is the width of the roadway and the edge of the fortified lanes. The value of these elements is accepted depending on the category of the road and should remain constant on straight sections of the route and on curves in terms of large radius since on the curves of small radius surfacing becomes wider [1-4].

The surfacing width and that of the sidewalks of the highway directly impacts the likelihood of an accident. E.g., in the case of a local narrowing of the surfacing on a multi-lane road, the likelihood of a collision of vehicles while overtaking with a change of lane goes up considerably compared to the overtaking with no maneuver.

The lane width is set depending on the speed and dimensions of vehicles. Insufficient lane width does not provide safe traffic with design speeds and a permissible level of risk, excessive width increases the cost of one of the most costly elements of the road, i.e., surfacing when the risk level is less than acceptable.

Lane change schemes for overtaking a slow-moving car can vary considerably, both in the direction of the maneuver (left, right) and in the composition of the vehicles involved in the reconstruction. Note that in the suggested mathematical models of risk theory, any schemes of interaction of cars are applicable, but as the major scheme of movement of vehicles should rely on the most dangerous scheme of reconstruction of cars. One of the most dangerous scenario is when traffic schemes on the six-lane highway will the scheme of changing the lane by a large class bus from the right extreme lane to the middle one (Fig. 1). At the same time, the change of lane with a maneuver to the left corresponds to the bus ahead of the train (see Fig. 1), when a car with the calculated speed for this category of road moves along the extreme left lane in the same line. Maneuvering a bus on a six-lane highway is acceptable as the bus is carrying people, has large dimensions and can develop high speeds making accidents involving the bus classed as severe. The most dangerous scenario is when the bus is near the 
road train (in the middle lane) as a result of a lane change and all vehicles, including a car, are in one line along the width of the roadway (Fig. 1) [11, 12, 14-20].

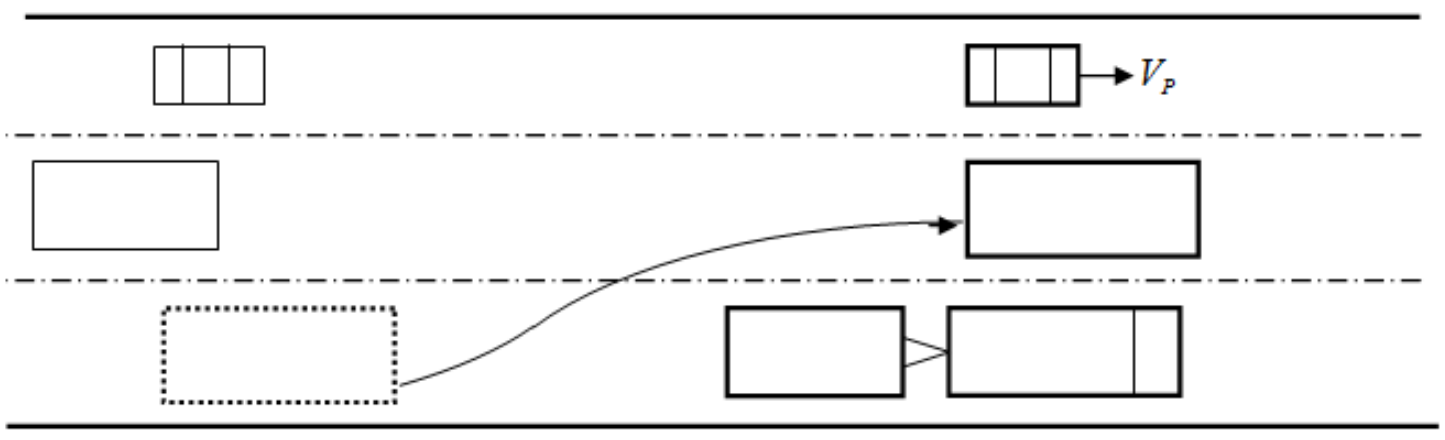

Fig. 1. Scheme for identifying the risk of overtaking on a six-lane highway: $V_{p}-$ is the design speed of a vehicle

The above scheme corresponds to the actual and most dangerous reconstruction on the sixlane highway. Note that the most dangerous scenario is when the train feels the reconstruction, but such a scheme is less realistic and can be seen as an exception. Note that while using this mathematical model created by designers, it is necessary to apply the composition of the movement of vehicles, which is justified in the design of the highway. Types of vehicles (Fig. 2), located in one line and their main dimensions are taken according to Table 1 [13].

Table 1

Dimensional characteristics of vehicles

\begin{tabular}{|l|c|c|c|}
\hline & Vehicle & Intercity bus \\
GAZ 3110 «olga») & Setra S411 & Road train \\
\hline Width, $\mathrm{m}$ & $a_{1}=1.80 \mathrm{~m}$ & $a_{2}=2.55 \mathrm{~m}$ & $a_{3}=2.04 \mathrm{~m}$ \\
\hline Rut, $\mathrm{m}$ & $c_{1}=1.5 \mathrm{~m}$ & $c_{2}=1.80 \mathrm{~m}$ & $c_{3}=2.15 \mathrm{~m}$ \\
\hline Length, $\mathrm{m}$ & $D_{1}=4.921 \mathrm{~m}$ & $D_{2}=10.465 \mathrm{~m}$ & $D_{3}=16.50 \mathrm{~m}$ \\
\hline
\end{tabular}

Therefore in this article the risk [5-10] of interaction of vehicles on the six-lane highway with the central dividing strip where the likelihood of a road accident during overtaking with a change of a lane is predicted is given by the formula:

$$
r_{\text {Д.У. }}=0,5-\Phi\left(\frac{B_{\Pi P}-B_{K P}}{\sqrt{\left(\sigma_{B_{\Pi P}^{\partial o n}}^{2}\right)^{2}+\sigma_{B_{K P}}^{2}}}\right),
$$

where $B_{\Pi P}-$ is the design surfacing width (a reinforced surface) in one direction of movement, including the width of a three-lane carriageway and that of the reinforced lanes on the 
right sidewalk and the central dividing lane. (At separate designing of counter directions of movement the parameter $B_{\Pi P}$ includes the width of the reinforced lanes on both roadways), m; $B_{K P}-$ is the critical width of the coating corresponding to the $50 \%$ risk of an accident (where the bus maneuvers, and the car and train travel in the extreme left and right lanes, respectively). At the same time the bus maneuvers from the extreme right lane to the middle one overtaking the road train; $\sigma_{B_{\Pi P}}^{\text {don }}-$ is the permissible descending standard deviation of the width of the surfacing, $\mathrm{m} ; \sigma_{B_{K P}}^{2}-$ is the standard deviation of the critical width of the surfacing, $\mathrm{m}$.
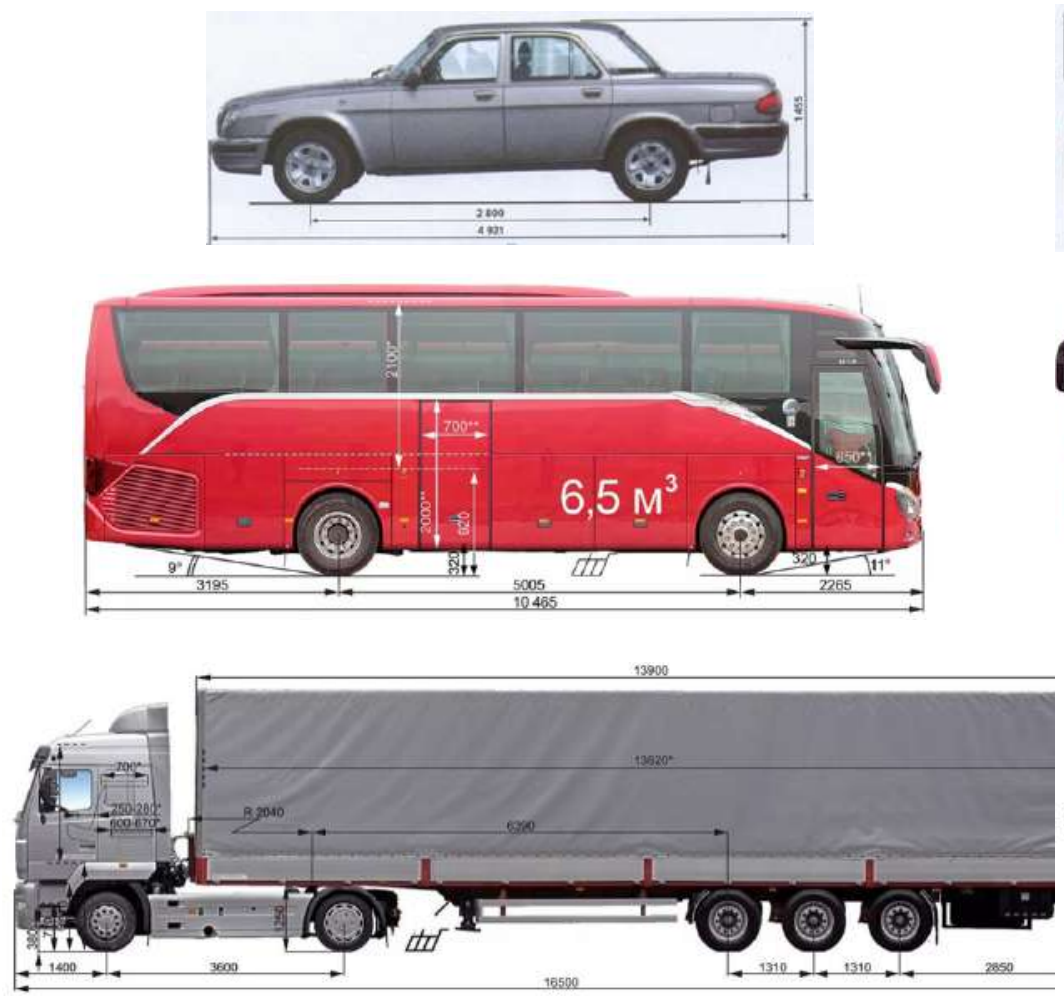
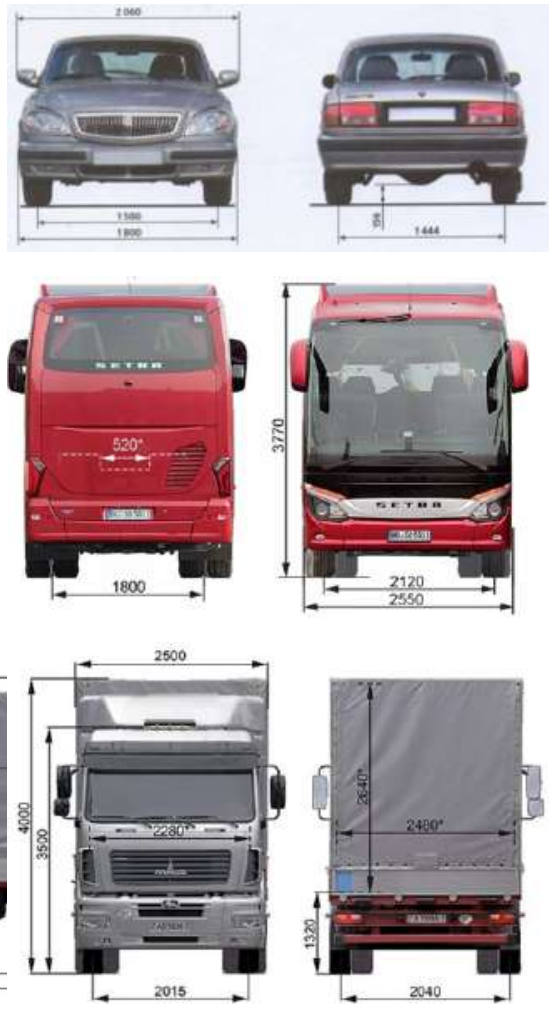

Fig. 2. Dimensional characteristics of vehicles taken into consideration

This approach enables one to address the following problems:

- to identify the risk of the width parameters of the six-lane road normalized in the current GOST (ГОСТ) and SP (СП);

- to design the surfacing width with the permissible value of the risk of collision of vehicles ahead of the change of lanes (for any parameters of vehicles on the multi-lane roadway);

- to improve the cross-sections of existing multi-lane roads based on assessing and reducing the risk of accidents to a permissible value in the process of maneuvering ahead of high-speed vehicles of low-speed vehicles on the multi-lane roadway; 
- to develop guidelines for changing the organization of traffic on existing roads (with a justification of the permissible speeds indicated on signs 3.24, at which the risk of collision of vehicles will be permissible).

\section{Method of normalization of parameters of width of the surfacing of a six-lane road.}

Input parameters. Vehicle speeds:

- a car (GAZ 3110 "Volga"), as already noted, is moving at a design speed for this category of six-lane road $\left(V_{1}=V_{p}=120 \mathrm{~km} / \mathrm{h}=33,33 \mathrm{~m} / \mathrm{sec}\right)$;

- the Setra S411 intercity bus maneuvers at the speed $80 \mathrm{~km} / \mathrm{h}=22,22 \mathrm{~m} / \mathrm{sec}$;

- road train, moving at the speed $70 \mathrm{~km} / \mathrm{h}=19,44 \mathrm{~m} / \mathrm{sec}$;

- lane width $3.75 \mathrm{~m}$.

While driving on the inner lane of the car with the calculated speed, the risk of overtaking a large vehicle Setra S411 intercity bus on the normalized width of the surfacing according to the following procedure.

1. The critical width of the surfacing where $50 \%$ of road accidents occur is given by the dependence

$$
B_{K P}=\frac{D_{1} \times V_{1}}{200}+\frac{a_{1}+c_{1}}{2}+\frac{\left(D_{2}+3,6\right) \times V_{2}}{200}+a_{2}+\frac{D_{3} \times V_{3}}{200}+\frac{a_{3}+c_{3}}{2}
$$

where $V_{1}$ - is the speed of the car (GAZ 3110 "Volga" equalling the calculated speed for the projected road, $\mathrm{m} / \mathrm{s} ; V_{2}$ - is the speed of the lane-shifting maneuver intercity bus Setra S411, $\mathrm{m} / \mathrm{sec} ; V_{3}$ - is the movement of the road train being overtaken, $\mathrm{m} / \mathrm{sec} ; D_{1} . D_{2} . D_{3}-$ are the lengths of the corresponding vehicles, $\mathrm{m} ; a_{1} \cdot a_{2} . a_{3}$ - is the width of the vehicles, $\mathrm{m} ; c_{1} \cdot c_{3}$ are ruts of the vehicles in the edge lanes, $\mathrm{m}$.

$$
\begin{gathered}
B_{K P}=\frac{4.921 \times 33.33}{200}+\frac{1.8+1.5}{2}+\frac{(10.465+3.6) \times 22.22}{200}+2.55+ \\
+\frac{16.5 \times 19.44}{200}+\frac{2.04+2.15}{2}=10.28(\mathrm{~m})
\end{gathered}
$$

2. The standard deviation of the critical width of the surfacing is given by the expression

$$
\begin{gathered}
\sigma_{B_{K P}}=\frac{\sqrt{\left(D_{1} \times V_{1}\right)^{2}+\left(D_{2}+3.6\right)^{2} \times V_{2}^{2}+\left(D_{3} \times V_{3}\right)^{2}}}{600}= \\
=\frac{\sqrt{(4.921 \times 33.33)^{2}+(10.465+3.6)^{2} \times 27.7^{2}+(16.5 \times 19.44)^{2}}}{600}= \\
=0.79(\mathrm{~m}) .
\end{gathered}
$$


3. Permissible standard deviation $\left(\sigma_{B_{I I P}}^{\partial o n}\right)$ of the width of the surfacing in one direction of movement is given by the formula [5]:

$$
\sigma_{B_{\Pi P}}^{\partial o n}=\sigma_{B_{H}}^{\partial o n}=2.45 \times \Delta_{\partial o n} \times\left(\frac{B_{\Pi P}}{d}\right)^{2}
$$

where $\Delta_{\partial o n}-$ is the the permissible deviation of the surfacing width relative to the design surfacing width $\left(\Delta_{\partial o n}=0.06\right)$, m; (see SP (CП) 78.13330.2012 Highways. Enabled edition of SNiP (СНиП) 3.06.03-85); $B_{\Pi P}=B_{H}$ is the normalized width of the surfacing in one direction of the road, (m). The value of the parameter $B_{H}(\mathrm{~m})$ is identified dependeing on the structure of a transverse profile. In a six-lane road, the cross-section consists of three lanes in one direction of $3.75 \mathrm{~m}$, the edge lane of $0.75 \mathrm{~m}$ and the edge lane of the dividing lane of $1 \mathrm{~m}$.

$$
B_{H}=3 \times 3.75+0.75+1=13.00(m)
$$

$d-$ is the normalized (permissible) distance between the diameters $(\mathrm{m})$, through which the measured deviation while assigning the road into operation $\left(\Delta_{i}=B_{i}-B_{H}\right)$ should not exceed the permissible deviation $\left(\Delta_{\partial o n}=0.06\right)$, of the surfacing width. At smaller distances between the diameters than the normalized one $d$, the actual deviations of the surfacing width from the design width must be less than $6 \mathrm{~cm}(0.06 \mathrm{~m})$. The value of the parameter $d(\mathrm{~m})$ is identified depending on the calculated speed of movement depending on (4).

$$
d=0.147 \times V_{p} \times 3.6=0.147 \times 120 \times 3.6=17.64(m),
$$

where $V_{p}-$ is the design speed in this road category, $\mathrm{km} / \mathrm{h}$.

$$
\sigma_{B_{\Pi P}}^{\partial o n}=\sigma_{B_{H}}^{\partial o n}=2.45 \times 0.06 \times\left(\frac{13.00}{17.64}\right)^{2}=0.08(m) .
$$

4. The risk of an accident on a six-lane highway when a low-speed vehicle is being overtaken by a high-speed vehicle (intercity bus Setra S411) is given by formula (1).

$$
r_{\text {Д.У. }}=0.5-\Phi\left(\frac{B_{\Pi P}-B_{K P}}{\sqrt{\left(\sigma_{\left.B_{\Pi P}^{\text {on }}\right)^{2}+\sigma_{B_{K P}}^{2}}\right.}}\right)=0.5-\Phi\left(\frac{13.00-10.28}{\sqrt{0.08^{2}+0.79^{2}}}\right)=0.00033 .
$$

Conclusions:

1. According to the resulting risk, 3 cars from 10000 on the six-lane highway in one direction of movement will be involved in a road accident due to the insufficient width of the surfacing.

2. Regulatory documents for the design of six-lane roads in the design composition of vehicles should allow for a change in the standard width of the surfacing, increasing it to a value where the risk of collision of cars does not exceed the permissible one $1 \times 10^{-4}$. 
This solution is in compliance with the requirements of the law №184 "On Technical Regulation" (risk management by reducing to a permissible value) and government decree № 806 from 17.08.2016 on the application of the risk-based approach [3].

\section{Design of the surfacing width with a permissible value of risk of collision of vehicles} (at any parameters of vehicles on a multi-lane carriageway).

The algorithm for addressing this problem is the same as the one proposed for the first problem and is applied when the standard surfacing width does not allow for maneuvering of vehicles with an acceptable value of risk $\left(1 \times 10^{-4}\right)$.

While designing the surfacing width, the iterative process of changing it should be employed until the risk of a car collision is reduced to a permissible value. Iterations begin with an increase in the design surfacing width in one direction of the road causing a decrease in the identified risk according to formula (1). The surfacing width where the risk of collision of cars in front will be less than or equal to the allowable risk $\left(1 \times 10^{-4}\right)$ is accepted as the required width provided that traffic on six-lane roads is safe.

We accept the increased surfacing width according to the following scheme:

$B_{\Pi P}-$ is design surfacing width in one direction of the six-lane road, (m). The value of the parameter $B_{\Pi P}(\mathrm{~m})$ is determined depending on the design of the cross section. On the six-lane road, the transverse profile consists of three lanes in one direction of $3.75 \mathrm{~m}$, the changed width of the safety lane on the roadside $-1.00 \mathrm{~m}$, with the same value of the edge lane on the central dividing lane $-1.00 \mathrm{~m}$.

$$
B_{\Pi P}=3 \times 3.75+1.00+1.00=13.25(m) ;
$$

The permissible descending standard deviation $\left(\sigma_{B_{\Pi P}}^{\partial o n}\right)$ of the surfacing width in one direction of movement is given by formula (4).

$$
\sigma_{B_{\Pi P}^{\partial o n}}^{\partial}=2.45 \times \Delta_{\partial o n} \times\left(\frac{B_{\Pi P}}{d}\right)^{2}=2.45 \times 0.06 \times\left(\frac{13.25}{17.64}\right)^{2}=0.083(\mathrm{~m}) .
$$

Then, the risk of an accident on a six-lane highway, when a low-speed vehicle is being overtaken by a high-speed car (intercity bus Setra S411) according to formula (1) is equal to:

$$
r_{\text {Д.У. }}=0.5-\Phi\left(\frac{B_{\Pi P}-B_{K P}}{\sqrt{\left(\sigma_{B_{\Pi P}{ }^{\partial o n}}^{2}+\sigma_{B_{K P}}^{2}\right.}}\right)=0.5-\Phi\left(\frac{13.25-10.288}{\sqrt{0.083^{2}+0.806^{2}}}\right)=0.000102 .
$$

Conclusion:

1. This iteration has generated a permissible value of the risk of collision of cars during overtaking with a change of lane. The surfacing width increased by $0.25 \mathrm{~m}$. 
2. In compliance with the risk-oriented approach to the production of safe products, based on the requirements of the law №184 "On Technical Regulation", this solution should be made as justified in relation to the required surfacing width.

4. Improving the cross-section of the existing six-lane road (based on the assessment and reduction of the risk of accidents to a permissible value in the process of maneuvering ahead of high-speed vehicles on low-speed vehicles on the multi-lane carriageway). The risk of interaction of vehicles on the existing six-lane highway where there might be an accident ahead of the change of lane is given by formula (1). In this case, its designations are as follows: $B_{\Pi P}=B_{C P}$ is the average actual surfacing width (reinforced surface) in one direction of movement, including the width of the three-lane carriageway and the width of the reinforced lanes on the right sidewalk and the central dividing strip. (At independent tracing of counter lanes the parameter $B_{C P}$ includes the width of the strengthened lanes on both roadsides), $\mathrm{m}$; The value $B_{C P}$ is determined in the process of surveying the surfacing width by means of the formulas of statistical analysis.

In this case $B_{C P}=12.71(\mathrm{~m})$;

$\sigma_{B_{\Pi P}}^{\partial o n}=\sigma_{B_{C P}}^{2}$ which is the actual standard deviation $\left(\sigma_{B_{\Phi}}\right)$ of the surfacing width in one direction of movement is identified during the in-house processing of the measured surfacing width by means of the statistical analysis methods. In our example, let $\sigma_{B_{\Phi}}=0.37(\mathrm{~m})$;

Input parameters:

Vehicle speeds:

— car (GAZ 3110 "Volga"), as already noted, is moving at a calculated speed for this category of six-lane $\operatorname{road}\left(V_{1}=V_{p}=120 \mathrm{~km} / \mathrm{h}=33.33 \mathrm{~m} / \mathrm{sec}\right)$;

— intercity bus Setra S411 maneuvres at the speed $80 \mathrm{~km} / \mathrm{h}=22.22 \mathrm{~m} / \mathrm{sec}$;

— road train moving at the speed $70 \mathrm{~km} / \mathrm{h}=19.44 \mathrm{~m} / \mathrm{sec}$ along the width of the traffic lane of $3.75 \mathrm{~m}$.

While driving on the inner lane of the car with the calculated speed, the risk of the large vehicle Setra S411 overtaking the intercity bus on the actual (operated) surfacing width according to the following procedure.

1. The critical surfacing width where $50 \%$ of road accident occur is given by dependence (2)

$$
\begin{gathered}
B_{K P}=\frac{4.921 \times 33.33}{200}+\frac{1.8+1.5}{2}+\frac{(10.465+3.6) \times 22.22}{200}+2.55+ \\
+\frac{16.5 \times 19.44}{200}+\frac{2.04+2.15}{2}=10.28(\mathrm{~m}) .
\end{gathered}
$$


2.The standard deviation of the critical width of the coating is given by the expression (3)

$$
\sigma_{B_{K P}}=\frac{\sqrt{(4.921 \times 33.33)^{2}+(10.465+3.6)^{2} \times 27.7^{2}+(16.5 \times 19.44)^{2}}}{600}=0.79(\mathrm{~m}) .
$$

3. The risk of an accident on an existing six-lane motorway while a low-speed vehicle is being overtaken by a high-speed vehicle (Setra S411 intercity bus) is given by formula (1).

$$
r_{\text {Д.У. }}=0.5-\Phi\left(\frac{B_{\Pi P}-B_{K P}}{\sqrt{\left(\sigma_{B_{\Pi P}^{\partial o n}}^{2}+\sigma_{B_{K P}}^{2}\right.}}\right)=0.5-\Phi\left(\frac{12.71-10.28}{\sqrt{0.37^{2}+0.79^{2}}}\right)=0.00281 .
$$

Conclusions:

1. According to the resulting risk, 28 cars out of 10.000 (or 3 cars out of 1.000) in a six-lane highway in one direction will be involved in the collision due to the insufficient width of the surfacing and the low quality of its construction.

2. The permissible risk on the existing roads built before the application of Federal Law № 184 "On Technical Regulation" is $1 \times 10^{-3}$.

3. Let us look at the increase in the surfacing width in one direction of movement to $12.81 \mathrm{~m}$, and reducing the standard deviation of this width to $0.20 \mathrm{~m}$. Based on this solution according to formula (1), the risk of an accident for the above composition of traffic importance on the existing roads is $1 \times 10^{3}$ :

$$
r_{\text {Д.У. }}=0.5-\Phi\left(\frac{B_{\Pi P}-B_{K P}}{\sqrt{\left(\sigma_{B_{\Pi P}^{\text {don }}}^{2}\right)^{2}+\sigma_{B_{K P}}^{2}}}\right)=0.5-\Phi\left(\frac{12.81-10.28}{\sqrt{0.20^{2}+0.79^{2}}}\right)=0.00102 .
$$

Thus while improving the cross-section of the existing multi-lane road, the average surfacing width should be at least $12.81 \mathrm{~m}$, and the standard deviation of the surfacing width should not exceed $0.20 \mathrm{~m}$.

\section{Conclusions:}

1. The technique of normalizing the surfacing width of a multilane road (for the development of GOST (ГОСТ) and SP (СП) or for checking the conformity of the normalized parameters to the required ones) based on calculating and reducing the risk of collision of vehicles on a six-lane road to an admissible level of risk is shown;

2. Mathematical models and methods of design of the surfacing width based on the compliance with an acceptable or admissible risk of collision of vehicles during overtaking with a change of lanes (at any parameters of vehicles on a multilane carriageway) have been developed; 
3. The algorithm is presented for improving the parameters of cross profiles of the existing multilane roads based on the estimation and reduction of risks of road accidents to a permissible value in the course of maneuvering when slow-moving vehicles are being overtaken by high-speed cars on a multilane carriageway.

\section{References}

1. Vetrogon A. A., Kripak M. N. Transportnoe modelirovanie kak instrument dlya effektivnogo resheniya zadach v oblasti upravleniya transportnymi potokami [Transport modeling as a tool for effective solution of problems in the field of traffic flow management]. Sovremennye tekhnologii. Sistemnyi analiz. Modelirovanie, 2018, no. 3 (59), pp. 82-91.

2. Granovskii V. A., Odintsov A. E. Metody sbora i obrabotki informatsii transportnykh potokov [Methods of collecting and processing information of transport flows]. Avtomobil'naya promyshlennost', 2015, no. 2, pp. 25-26.

3. Danilkin V. A., Trukhachev A. A., Beltov A. G. Postroenie modeli perestroeniya transportnym sredstv v transportnykh potokakh [Construction of a model of rebuilding vehicles in transport flows]. Programmnaya inzheneriya, 2012, no. 6, pp. 30-34.

4. Starozhilets V. M., Chekhovich Yu. V. Ob identifikatsii statisticheskoi modeli transportnykh potokov s ispol'zovaniem grupp avtomobil'no-transportnykh sredstv [On the identification of a statistical model of transport flows using groups of motor vehicles]. Mashinnoe obuchenie $i$ analiz dannykh, 2017, vol. 3, pp. 193-202.

5. Stolyarov V. V., Shchegoleva N. V. Opredelenie dopustimykh srednekvadraticheskikh otklonenii geometricheskikh parametrov avtomobil'nykh dorog [Determination of permissible standard deviations of geometric parameters of highways]. Dorogi i mosty, 2018, vol. 38, p. 5.

6. Stolyarov V. V. Proektirovanie avtomobil'nykh dorog po usloviyu obespecheniya bezopasnosti dvizheniya s ispol'zovaniem teorii riska. Diss. d-ra tekhn. nauk [Designing highways according to the condition of ensuring traffic safety using the theory of risk. Cand. eng. sci. diss.]. Saratov-Moscow, 1995. 337 p.

7. Stolyarov V. V. Proektirovanie avtomobil'nykh dorog s uchetom teorii riska $: v 2 \mathrm{ch}$. [Designing highways taking into account the theory of risk. Part 1]. Saratov, Sarat. gos. tekhn. un-t Publ., 1994. 184 p.

8. Stolyarov V. V. Dorozhnye usloviya i organizatsiya dvizheniya s ispol'zovaniem teorii riska [Road conditions and traffic organization using the theory of risk]. Saratov, SGTU Publ., 1999. 168 p.

9. Stolyarov V. V., Gusev V. A., Shchegoleva N. V. [Speed limit according to the permissible risk for ensuring traffic safety on difficult sections of highways]. Sb. tr. uchastnikov 11-i mezhdunar. nauch.-prakt. konf. "Organizatsiya i bezopasnost' dorozhnogo dvizheniya v krupnykh gorodakh" [Proc. "Organization and safety of road traffic in large cities"]. Saint-Petersburg, 2014, pp. 369-379.

10. Stolyarov V. V., Shchegoleva N. V., Kokodeeva N. E., Kochetkov A. V. Primery rascheta geometricheskikh, transportno-ekspluatatsionnykh i prochnostnykh parametrov avtomobil'nykh dorog na osnove teorii riska. Ch. I. Proektirovanie [Examples of calculating geometric, transport-operational and strength parameters of highways based on the risk theory. Part I. Design]. Saratov, Sarat. gos. tekhn. un-t Publ., 2017. 272 p.

11. Teben'kov S. E., Levashev A. G. Rezul'taty otsenki raspredeleniya transportnykh potokov v transportnykh koridorakh [Results of the assessment of the distribution of transport flows in transport corridors]. Vestnik 
Irkutskogo gosudarstvennogo tekhnicheskogo universiteta, 2011, no. 10 (57), pp. 120-127.

12. Torobekov B. T., Okhotnikov V. I. Razvitie transportnoi logisticheskoi sistemy putem monitoringa transportnogo potoka [Development of the transport logistics system by monitoring the transport flow]. Izvestiya Kyrgyzskogo gosudarstvennogo tekhnicheskogo universiteta im. I. Razzakova, 2017, no. 4 (44), pp. 428 -433.

13. Tekhnicheskie kharakteristiki avtomobilei [Technical characteristics of cars]. Available at: http://avtomarket.ru/catalog/

14. Ishihara Y., Sugawara T. Analysis of Traffic Congestion Reducer Agents on Multi-Lane Highway. Proceedings - 2019 2nd International Conference on Intelligent Autonomous Systems, ICoIAS 2019, 2019, pp. $135-141$.

15. Jiao X., Yang D., Jiang K., Wen T., Yan R. Real-time lane detection and tracking for autonomous vehicle applications. Proceedings of the Institution of Mechanical Engineers, Part D. Journal of Automobile Engineering, 2019, no. 233 (9), pp. 2301-2311.

16. Mandžuka S. Lecture Notes in Networks and Systems. Intelligent Mobility, 2020, pp. 367-376.

17. Mestri R. A., Garg R. D. Identification and Removal of Accident-Prone Locations Using Spatial Data Mining. Lecture Notes in Civil Engineering, 2020, pp. 383-394.

18. Shin H.-S., Turchi D., He S., Tsourdos A. Behavior Monitoring Using Learning Techniques and RegularExpressions-Based Pattern Matching. IEEE Transactions on Intelligent Transportation Systems, 2019, no. 20 (4), pp. $1289-1302$.

19. Song D., Tharmarasa R., Florea M. C., Fernando X. N., Kirubarajan T. Multi-vehicle tracking with microscopic traffic flow model-based particle filtering. Automatica 105, 2019, pp. 28-35.

20. Szczuraszek T., Klusek R. Influence on the Type of Intersection on Road Traffic Safety in Poland. IOP Conference Series: Materials Science and Engineering, 2019, no. 471 (6), pp. 75-83. 